\title{
Review \\ Oxidative Stress in Arterial Hypertension (HTN): The Nuclear Factor Erythroid Factor 2-Related Factor 2 (Nrf2) Pathway, Implications and Future Perspectives
}

\author{
Daniela Maria Tanase 1,2,+(D), Alina Georgiana Apostol ${ }^{3,4}$, Claudia Florida Costea 5,6, \\ Claudia Cristina Tarniceriu $7,8,+$, Ionut Tudorancea $9,10, * \mathbb{D}$, Minela Aida Maranduca $9,+$, Mariana Floria ${ }^{1,11,+} \mathbb{D}$ \\ and Ionela Lacramioara Serban 9
}

Citation: Tanase, D.M.; Apostol, A.G.; Costea, C.F.; Tarniceriu, C.C.;

Tudorancea, I.; Maranduca, M.A.;

Floria, M.; Serban, I.L. Oxidative Stress in Arterial Hypertension (HTN): The Nuclear Factor Erythroid Factor 2-Related Factor 2 (Nrf2)

Pathway, Implications and Future Perspectives. Pharmaceutics 2022, 14 , 534. https://doi.org/10.3390/ pharmaceutics 14030534

Academic Editor: Yasumasa Ikeda

Received: 2 February 2022

Accepted: 25 February 2022

Published: 27 February 2022

Publisher's Note: MDPI stays neutral with regard to jurisdictional claims in published maps and institutional affiliations.

Copyright: (c) 2022 by the authors. Licensee MDPI, Basel, Switzerland. This article is an open access article distributed under the terms and conditions of the Creative Commons Attribution (CC BY) license (https:// creativecommons.org/licenses/by/ $4.0 /)$.
1 Department of Internal Medicine, "Grigore T. Popa" University of Medicine and Pharmacy, 700115 Iasi, Romania; tanasedm@gmail.com (D.M.T.); floria_mariana@yahoo.com (M.F.)

2 Internal Medicine Clinic, "St. Spiridon" County Clinical Emergency Hospital, 700115 Iasi, Romania

3 Department of Neurology, "Grigore T. Popa" University of Medicine and Pharmacy, 700115 Iasi, Romania; georgianaapostol07@gmail.com

4 Neurology Clinic, Clinical Rehabilitation Hospital, 700661 Iasi, Romania

5 Department of Ophthalmology, Faculty of Medicine, "Grigore T. Popa" University of Medicine and Pharmacy, 700115 Iasi, Romania; costea10@yahoo.com

6 2nd Ophthalmology Clinic, "Prof. Dr. Nicolae Oblu" Emergency Clinical Hospital, 700309 Iasi, Romania

7 Department of Morpho-Functional Sciences I, Discipline of Anatomy, "Grigore T. Popa" University of Medicine and Pharmacy, 700115 Iasi, Romania; cristinaghib@yahoo.com

8 Hematology Clinic, "St. Spiridon” County Clinical Emergency Hospital, 700111 Iasi, Romania

9 Department of Morpho-Functional Sciences II, Discipline of Physiology, "Grigore T. Popa" University of Medicine and Pharmacy, 700115 Iasi, Romania; minela.maranduca@umfiasi.ro (M.A.M.); ionela.serban@umfiasi.ro (I.L.S.)

10 Cardiology Clinic "St. Spiridon" County Clinical Emergency Hospital, 700111 Iasi, Romania

11 Internal Medicine Clinic, Emergency Military Clinical Hospital, 700483 Iasi, Romania

* Correspondence: ionut.tudorancea@umfiasi.ro

$\dagger$ These authors contributed equally to this work.

Abstract: Arterial hypertension (HTN) is one of the most prevalent entities globally, characterized by increased incidence and heterogeneous pathophysiology. Among possible etiologies, oxidative stress (OS) is currently extensively studied, with emerging evidence showing its involvement in endothelial dysfunction and in different cardiovascular diseases (CVD) such as HTN, as well as its potential as a therapeutic target. While there is a clear physiological equilibrium between reactive oxygen species (ROS) and antioxidants essential for many cellular functions, excessive levels of ROS lead to vascular cell impairment with decreased nitric oxide (NO) availability and vasoconstriction, which promotes HTN. On the other hand, transcription factors such as nuclear factor erythroid factor 2-related factor 2 (Nrf2) mediate antioxidant response pathways and maintain cellular reduction-oxidation homeostasis, exerting protective effects. In this review, we describe the relationship between OS and hypertension-induced endothelial dysfunction and the involvement and therapeutic potential of Nrf2 in HTN.

Keywords: arterial hypertension; HTN; nuclear factor erythroid factor 2-related factor 2; Nrf2; oxidative stress; antioxidant

\section{Introduction}

Arterial hypertension (HTN) represents a persistent increase in blood pressure (BP), measuring at least $140 / 90 \mathrm{mmHg}$ according to the European Society of Hypertension (ESH) and European Society of Cardiology (ESC), and it is one of the major risk factors for cardiovascular diseases (CVD) [1]. It is estimated that 1.13 billion people suffer from hypertension worldwide, making it the main cause of strokes and coronary heart disease 
(CHD). Therefore, approximately 8.5 million deaths per annum are attributed to raised BP [2]. Considering the context of the COVID-19 pandemic, it is worth mentioning that almost all available evidence up to this date suggests that HTN can be a risk factor of severe COVID-19 disease and can also become a serious sequela [3-6]. The etiology of hypertension, as it is complex and involves a myriad of varied factors, continues to remain one of the top scientific subjects of interest. While the role of inflammation and oxidative stress (OS) in HTN is currently extensively explored [7-10], the precise deleterious effect of HTN on endothelial integrity and the involvement of molecules such as the nuclear factor erythroid 2-related factor 2 (Nrf2) in the pathogenesis and evolution of raised BP remain elusive [11,12].

In this narrative review, we aim to describe the relationship between OS and hypertension-induced endothelial dysfunction and the role and therapeutic potential of Nrf2 in HTN.

\section{Oxidative Stress in Hypertension}

Oxidative stress is a process that takes place inside the cells and occurs in situations where there is an increased number of reactive oxygen species (ROS) or a low antioxidant response towards cell aggression [13-15]. There are several endogenous sources of ROS within cardiac myocytes, especially enzymes such as mitochondrial enzymes, nicotinamide adenine dinucleotide phosphate (NADPH) oxidase, xanthine oxidoreductase (XOR), and uncoupled endothelial nitric oxide synthase (eNOS) [16-18]. OS exerts its harmful effects on tissues by causing endothelial lesions and enlargement and thickening of the heart's walls, mainly of the left ventricle, thus serving as one of the main processes that lead to HTN and other CVDs [19]. Endothelial dysfunction is characterized by decreased NO, with or without an imbalance between endothelium-derived relaxing and contracting factors combined with a prothrombotic and a proinflammatory state [20].

An immense variety of enzymes work to keep the balance inside the cells. In addition, molecules such as glutathione and ascorbate act as direct antioxidants in increased blood pressure conditions [21]. For a long time, researchers have been investigating the precise role of OS as a generator or potential therapeutic target, not only in the pathophysiology of HTN [22], or in pulmonary hypertension [23,24], but also in endothelial dysfunction associated with other cardiovascular and metabolic diseases [25]. Therefore, we will briefly discuss the main precursors of OS and their involvement in HTN.

\subsection{ROS and Nitric Oxide}

ROS following OS have extremely harmful cardiac effects because the heart is a big consumer of oxygen $\left(\sim 8-15 \mathrm{~mL} \mathrm{O}_{2} / \mathrm{min} / 100 \mathrm{~g}\right.$ tissue while resting, and it can go up to more than $>70 \mathrm{~mL} \mathrm{O}_{2} / \mathrm{min} / 100 \mathrm{~g}$ tissue while exercising) [26,27]. During sustained physical activity, molecular $\mathrm{O}_{2}$ is no longer reduced to water, but to superoxide $\mathrm{O}_{2}-$. This free radical is the precursor to most of the other ROS: hydrogen peroxide $\left(\mathrm{H}_{2} \mathrm{O}_{2}\right)$, hydroxyl radical $(\cdot \mathrm{OH})$, singlet oxygen $\left(1 \mathrm{O}_{2}\right)$, and alpha-oxygen $(\alpha-\mathrm{O})$. ROS are also known to have benefits such as defense against pathogens, but increased levels can lead to cardiovascular apoptosis and ischemic injuries [28-30]. The main harmful processes exerted on cardiac myocytes are DNA and RNA damage, lipid peroxidation, deactivation of specific enzymes, and oxidation of amino acids [31]. Enhanced levels of ROS have been associated with HTN; however, new generations of protein targets that include ROS-forming or toxifying enzymes that could act as pharmacological agents are needed [32,33].

Nitric oxide (NO) is a colorless gas, a molecule produced by the myocardium in physiological conditions, and its major function is to dilate vessels. Decreased levels of NO are associated with cardiovascular diseases [34,35]. There are four known NOS isoforms: endothelial NOS (eNOS), found in cardiac and coronary endothelium; neuronal NOS (nNOS), found in cardiac cells; inducible NOS (iNOS), derived from neutrophils or myocytes in conditions of inflammation; and mitochondrial NOS (mtNOS), present in cardiac mitochondria [36,37]. The beneficial roles of NOS are mediating heart protec- 
tion, improving endothelial integrity, and decreasing injuries of reperfusion caused by ischemia [38]. In ischemic situations, NO accumulates and produces ROS, leading to cardiac insults [36]. Usually, eNOS is the main source of endothelium-derived NO [39]. In order to synthesize NO from eNOS, a series of cofactors are involved, and its disruption leads to a monomeric form of the enzyme, which is uncoupled, and instead of NO, superoxide is formed. Uncoupled eNOS has been observed in patients with essential hypertension and atherosclerosis $[40,41]$. Endogenously activated Nrf2 and eNOS are thought to play a role in OS induced by myocardial infarction [36]. Higashi et al. [42] studied deficiency of tetrahydrobiopterin (BH4), a cofactor for $\mathrm{NO}$ synthase, and concluded that $\mathrm{BH} 4$ restores endothelium-dependent vasodilation in hypertensive patients.

\subsection{Mitochondria}

Mitochondria have multiple functions, being a variable source of ROS under physiological conditions and maintaining the redox status inside cells [43]. The small amount of ROS produced during respiration is not dangerous, and it is detoxified by endogenous means. However, in hypoxic or ischemic conditions, mitochondria generate elevated levels of ROS, which increase the chances of apoptosis and even myocardial infarction (MI) [44]. An increasing number of studies have emphasized that mitochondria can produce high levels of ROS in hypertensive animal models [45-47]. Dikalov et al. [48] have shown in their study that endothelial tissue treated with angiotensin II increased mitochondrial ROS generation and the damage caused to the cells and the body systems, such as decreased membrane potential and decreased respiratory control ratio, respectively. Aside from the peripheral effects, ROS can regulate blood pressure via central mechanisms. Mitochondrial superoxide is overproduced in conditions of activated renin-angiotensin system (RAS) in the central nervous system (CNS) [49]. More than that, the mitochondrial ROS activate Nrf2 and promote the expression of genes involved in the control of mitochondrial and antioxidant genes via various protein kinases [50]. Taking into consideration the mitochondrial implications in cardiovascular pathophysiology, further studies could lead to new treatment strategies in hypertension.

\subsection{NADPH Oxidase (Nox)}

NADPH oxidase (Nox) is a membrane-bound enzyme complex considered an important source of ROS in cardiac cells. This is the only known category of enzymes specialized in producing ROS, and it was first described in immune cells such as macrophages and neutrophils as molecules with antimicrobial properties. The Nox family is comprised of Nox 1, Nox 2, Nox 3, Nox 4, Nox 5, dual oxidase 1 (Duox 1), and Duox 2 which in states of hyperactivity produce excessive levels of ROS, contributing to endothelial dysfunction, inflammation, and cardiovascular remodeling. Angiotensin II regulates Nox function in vessels [51-54]. Mice and rats treated with this peptide hormone expressed increased generation of ROS and enhanced activity of Nox 1, Nox 2, and Nox 4 [21]. In order to establish how Nox-produced ROS influence blood pressure, many researchers conducted genetic studies. Their results noted that in mice with Nox 1 deletion, hypertension cannot be induced by angiotensin II. Overexpression of human Nox 1 in experimental animals revealed increased blood pressure and aortic superoxide production as a result of angiotensin II action in vascular smooth muscle cells, ventricular hypertrophy, and oxidative stress [55]. In fibroblast-specific deficiency of Nox 2 knockout mice, the response to angiotensin II was considerably decreased. This resulted in a decreased hypertensive response and an inhibited vascular smooth muscle growth [56]. On the other hand, Nox 4 knockout mice infused with angiotensin II showed no change in blood pressure. However, in these mice, vascular inflammation, thickening of the media, and endothelial dysfunction have been noted, showing that Nox 4 exerts beneficial effects on the cardiovascular system. The experimental animals which developed hypertension were treated with nonspecific Nox inhibitors (apocynin or diphenylene iodonium) and the specific inhibitor gp91 ds-tat. Consequently, both the blood pressure and the vascular OS in those animals were lowered [21]. 
As is known, the glucose metabolism is altered in hypertension. The pentose phosphate pathway (PPP), also called the phosphogluconate pathway and the hexose monophosphate (HMP) shunt, acts as an essential element of cellular metabolism. The HMP shunt pathway plays a key role in NADPH2 and in ribose-5-phosphate formation and is involved in metabolic control by interacting with other metabolic pathways such as glycolysis, gluconeogenesis, and glucuronic acid. This pathway occurs in two phases that are illustrated by many reactions. The oxidative phase reactions are catalyzed by prostaglandin (PGD) and by the glucose-6-phosphate dehydrogenase (G6PD), both known to be controlled by Nrf2 [57,58]. G6PD is involved in the pathogenesis of pulmonary artery remodeling and occlusive lesion formation within the hypertensive lungs [59]. In the nonoxidative phase, NRF2 positively regulates the expression of transaldolase 1 (TALDO1) and transketolase (TKT) [58]. As deficiency in the HMP pathway can lead to different disorders, research data suggest the HMP shunt may have potential as a therapeutic target.

\section{4. $X O R$}

Xanthine oxidoreductase is an important source of superoxide and hydrogen peroxide in conditions of heart ischemia, inflammation, and OS. Its catalytic properties transform hypoxanthine to the end-product uric acid [60]. Mervaala et al. [61] studied the involvement of XOR in vascular damage induced by angiotensin II using double-transgenic rats (dTGRs) harboring human renin and human angiotensin genes. They showed that these rats presented overactivity of XOR in kidneys in contrast with control rats. The activity of the enzyme was successfully decreased using valsartan, an angiotensin II type 1 receptor antagonist. Moreover, valsartan, $30 \mathrm{mg} / \mathrm{kg}$ for three weeks, reduced not only blood pressure, but also cardiac hypertrophy and $24 \mathrm{~h}$ proteinuria. In the same study, oxypurinol, an XOR inhibitor, was used to preincubate renal arteries, resulting in an endotheliumdependent vascular relaxation by $20 \%$. However, it has been proven that ROS generated by XOR are not the major factors responsible for endothelial dysfunction in dTGRs and that other enzymes might play a major role in angiotensin II-induced vascular dysfunction in these rats [62].

Data so far show that OS and endothelial dysfunction are causes or consequences of HTN. Dysfunctional endothelium secondary to OS and its derivative molecules and pathways loses its capacity to protect the vessel wall, with the subsequent possibility of smooth muscle cell proliferation, monocyte adhesion, raised adhesion molecule expression, and finally development of atherosclerosis. Therefore, in order to prevent this vicious chain of events, researchers focus their attention on different pathways or molecules which contribute to OS-induced HTN.

\section{Nrf2}

Nrf2 was first discovered in 1994 by Moi et al. [63], and it is a nuclear transcription factor that plays a major role in regulating the cellular adaptive antioxidant response. It is a master regulator of cytoprotective responses [64]. Nrf2 does not have antioxidative functions but exerts antioxidant effects by activating the transcription of target antioxidant genes: HMOX-1, NQ01, MT1A, superoxide dismutase (SOD), catalase (CAT), glutathione peroxidase (GPx), glutathione-S-transferase (GST), and $\gamma$-glutamylcysteine synthase $(\gamma \mathrm{GCS})[65,66]$. Nrf2 is a polypeptide composed of 605 amino acids and 7 domains (Neh1, Neh2, Neh3, Neh4, Neh5, Neh6, Neh7). Kelch-like ECH-associated protein 1 (Keap1) inhibits Nrf2's transcriptional action by keeping it bound to itself under physiological conditions [67]. Keap1 is a polypeptide composed of 624 amino acid residues and 5 domains: NTR (N-terminus), IVR, BTB/POZ DGR, and CTR (C-terminus). Scientific research established in cell lines and animal models that Nrf2/Keap1 pathway activation exerts protective effects in ischemia-reperfusion injury in vessels [68].

Under oxidative stress conditions, Nrf2 can be phosphorylated by several enzymatic pathways. Protein kinase C phosphorylates Nrf2 on Ser40 and allows Nrf2 to detach from Keap1 [69]. Other kinases that can modulate Nrf2's activity include extracellular 
signal-regulated kinase (ERK) [70], phosphoinositide 3-kinases (PI3K) [71], AMP-activated protein kinase (AMPK) [72], and mitogen-activated protein kinase (MAPK) [73]. Phosphorylated Nrf2 (p-Nrf2) then binds to antioxidant response elements (AREs) in the nucleus, triggering the transcription of various genes which encode antioxidants, detoxifying enzymes, proteasomes, and antiapoptotic proteins aiming to scavenge excessive ROS. Nrf2 can also be activated through the canonical mechanism, where ROS oxidize part of the cysteine residues in Keap1, which in turn decreases Nrf2 ubiquitination and increases Nrf2 translocation to the nucleus, where the antioxidant transcription process can be initiated $[74,75]$. More than that, in Nrf2's activity, phosphorylation by kinases plays a vital role in its posttranslational regulation. Notably, glycogen synthase kinase-3 (GSK-3) regulates negatively, whereas AMP-activated kinase, casein kinase 2, and protein kinase C positively modulate Nrf2 activity via phosphorylation of various sites [76]. Nrf2 is the key activator of AREs [77] (Figure 1).

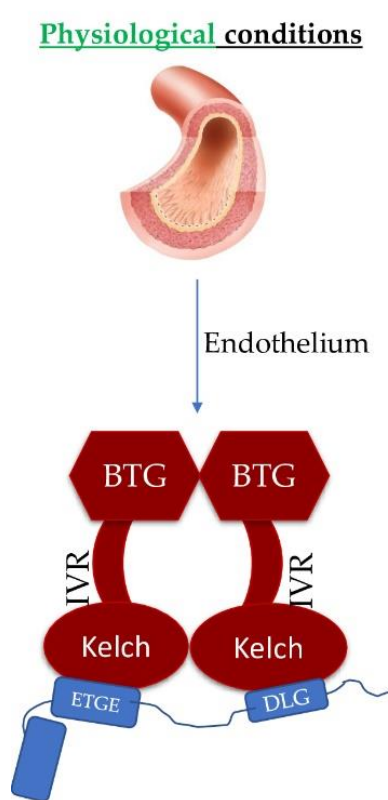

Nrf2-Keap1 complex

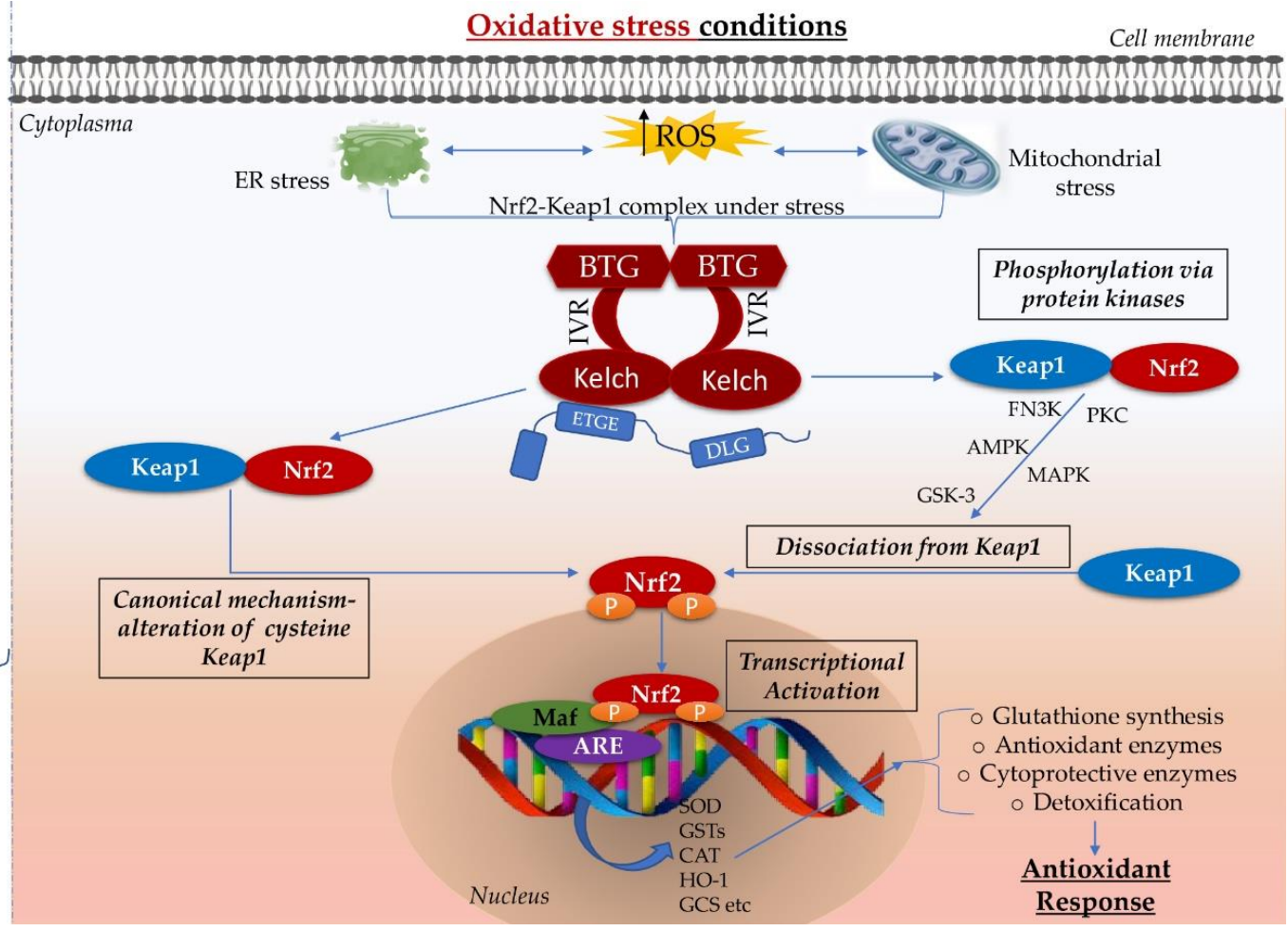

Figure 1. Role of the nuclear factor erythroid factor 2-related factor 2 (Nrf2) in oxidative stress. In physiological conditions, Nrf2 is bound to Keap1 (the key negative regulator and the inhibitory protein of Nrf2) and is secured to the actin cytoskeleton. This limits its transcriptional activity in the nucleus. Under OS conditions, the IVR domain leads to conformational alterations. Nrf2 is activated via canonical mechanism and/or via phosphorylation with secondary dissociation of Nrf2 from Keap1, which translocates into the nucleus and combines with the Maf protein to compose a heterodimer, capable of identifying the suitable ARE sequence. This activated ARE-mediated gene transcription is the Nrf2/Keap1-ARE pathway, which exerts antioxidant cellular functions via regulating the expression of antioxidant genes such as SOD, GST, CAT, and NQO1. Kelch-like $\mathrm{ECH}$-associated protein 1 (Keap1); intervening region (IVR); endoplasmic reticulum (ER); reactive oxygen species (ROS); antioxidant response element (ARE); musculoaponeurotic fibrosarcoma (Maf); superoxide dismutase (SOD); glutathione S-transferases (GSTs), catalase (CAT); heme oxygenase-1 (HO-1); glutamylcysteine synthetase (GCS); protein kinase C (PKC); fructosamine-3-kinase (FN3K); AMP-activated protein kinase (AMPK); mitogen-activated protein kinase (MAPK).

Although Nrf2 has been portrayed as an effective agent to protect the heart, its destructive side has been of current interest [78]. Kannan et al. [79] noted in 2013 that sustained 
activation of Nrf2 can also lead to cardiac dysfunction. Others have stressed the protective role of Nrf2 in the first phase of pressure overload-induced adaptation of the heart, while the Nrf2 KO showed a decreased rate of cardiac hypertrophy and recovery of cardiac function by eight weeks after transverse aortic arch constriction in rodents [80]. Considering both sides of Nrf2, it is clear that further research regarding how this transcription factor can affect the heart and blood vessels at a molecular level is needed.

\section{Nrf2 in Hypertension}

A gamut of evidence displays the key role of Nrf2 in cardiovascular diseases [81]; in metabolic disorders [82], diabetes [83,84], or obesity [85-87]; and even in autoimmune, gastrointestinal, and neurodegenerative diseases or cancer [88].

Endothelial dysfunction represents a crucial step in the development of atherosclerosis. As it needs to be prevented by means of antioxidative processes, Nrf2 may represent a modality to protect cells against endogenous and exogenous oxidants and thus prevent endothelial dysfunction onset [89].

Associated with Nrf2, peroxisome proliferator-activated receptor gamma (PPAR $\gamma$ ) is a nuclear receptor and a nutritional factor that is involved in inflammation response and homeostatic control by stimulating the expression of antioxidant genes together with the retinoid X receptor (RXR) [90]. It acts as a modulator of different pathways, such as Nrf2, RAS, and P13/Akt/NOS [91]. Blood pressure regulation, improved lipid profile and anti-inflammatory response, and ameliorated sensitivity to insulin are amongst the beneficial effects of PPAR $\gamma$ [92].

ROS produced during inflammation can activate Nrf2 and the nuclear factor kappalight-chain-enhancer of activated B cells (NF-kB). Once activated, Nrf2 attenuates ROS and consequently NF-kB activity [88]. Therefore, Nrf2 and NF-kB are both transcription factors that mediate the cellular response under conditions of OS and inflammation. NF-kB plays an important role in inducing the expression of multiple proinflammatory genes, such as those encoding chemokines and cytokines $[93,94]$. As a consequence, disrupted NF-kB activation contributes to the pathogenesis of multiple inflammatory diseases. Bhandari et al. [95] proposed a potential interplay between Nrf2 and NF-kB, where each pathway could inhibit the transcription activity of the other factor. Moreover, this crosstalk appears to work both ways, with Nrf2 having the ability to inhibit NF-kb and the other way around. Other transcription factors that activate Nrf2 are the aryl hydrocarbon receptor (AhR), specificity protein 1 (Sp-1), myocyte-specific enhancer factor 2 D (MEF2D), p53, c-Myc, c-Jun, and breast cancer 1 (BRCA1) [78]. Additionally, recent evidence displays the major role of Nrf2 in protecting against OS and inflammation by stimulating phase II antioxidant enzymes such as glutathione S-transferase (GST), UDP-glucuronosyltransferase (UGT), UDP-glucuronic acid synthesis enzymes, and HO-1 [96,97]. Nrf2 also exerts its anti-inflammatory effect by binding to the promoter sequence of the key proinflammatory cytokines (IL-1 $\beta$, IL-6) and by reducing the activity of RNA polymerase II, which will result in the suppression of gene expression [98].

The link between OS and HTN has already been proven in several animal models, but there is still room for research to also prove this in humans. Lopes et al. [99] used male Wistar Kyoto rats (WKY) and stroke-prone spontaneously hypertensive rats (SHRSP) to study how the vascular Nrf2 system influences vascular function and redox signaling. Nrf2 was downregulated in SHRSP in conditions of increased vascular OS which was connected with vascular dysfunction. However, Nrf2 activators, bardoxolone and L-sulforaphane, blocked the formation of angiotensin II-induced ROS, resulting in restored endothelial dysfunction and decreased inflammation in both WKY and SHRSP cells. Therefore, the author stresses the vasoprotective function of Nrf2 in HTN.

Another study performed by Banday and Lokhandwala [100] also investigated the role of Nrf2 in decreasing OS and BP in rats. Rats treated with L-buthionine-sulfoximine (BSO) were used to test whether sulforaphane could lower OS, decrease BP, and repair renal dopamine receptors (D1Rs). The study has successfully demonstrated the hypothesis 
that by activating Nrf2, the phase II antioxidant enzymes are generated, which leads to decreased OS and a well-functioning D1R system. These findings confirm that the use of sulforaphane helps in keeping BP in a normal range.

Tan et al. [69] have recently studied how the Nrf2 pathway decreases OS in the rostral ventrolateral medulla (RVLM) and whether Nrf2 intervenes in $\beta$-arrestin1's antihypertensive action. RVLM is one of the key areas involved in the regulation of BP and sympathetic activity. $\beta$-Arrestin 1 is a cytosolic protein acting as a cofactor in the desensitization of $\beta$-adrenergic receptors [101]. The results confirmed the antihypertensive role of the overexpression of $\beta$-arrestin1 in the RVLM by activating the Nrf2 pathway and increasing the generation of antioxidant enzymes. All these reactions lead to a decreased sympathetic outflow and a reduced BP value.

High BP caused by kidney diseases is often called renal HTN or renovascular HTN. It is important to mention that HTN could be both a cause and an effect of chronic kidney disease [102]. The renin-angiotensin-aldosterone (RAAS) system is responsible for regulating BP and electrolyte and fluid balance in the kidneys. The activation of this hormone system generates angiotensin II, which stimulates in turn the production of aldosterone. Aldosterone is the main mineral corticosteroid hormone, and its main function is to preserve sodium and water in the kidneys, thus causing the BP to increase [103-105]. Xiao et al. [106] discovered that in mice suffering from chronic heart failure which overexpressed angiotensin-converting enzyme 2 (ACE2), the sympathetic output was remarkably low. Others studied the hypothesis that ACE2 could decrease ROS generation using a pathway involving Nrf2 and antioxidant enzymes in the RVLM. The study succeeded in proving that both ACE2 and Nrf2 have the ability to inhibit sympathetic activity in HTN and chronic heart failure when they are administered in the RVLM [107]. Others noted in hypertensive rodent models that via OS and endothelial dysfunction, HTN could be one of the causes of Nrf2 transcriptional misregulations and not the other way around [99,108]. By cause of raised levels of Nrf2 repressors in hypertensive models, these results imply that the Nrf2 antioxidant defense system is insufficient to counteract the effects of OS.

Current scientific research focuses more on discovering specific factors linked to an inadequate Nrf2 signaling system, rather than on the Nrf2 antioxidant adaptative responses [108]. Nonetheless, perhaps amplifying Nrf2 activity may hold therapeutic potential for ameliorating HTN.

\section{Therapeutic Options in HTN}

The pharmacological Nrf2 activators are electrophilic compounds that can modify cysteine residues in Keap1 and ultimately its conformation through oxidation/alkylation. This process induces inhibition of Keap1-mediated degradation of Nrf2, with a consequently raised load of newly synthesized Nrf2, which augments Nrf2 transcription functions [109]. As follows, these "Nrf2 activators" actually represent Keap1 inhibitors [110].

The antioxidant defense system represented by the Nrf2 activators may include a wide range of compounds and derivatives with great potential in chronic diseases; however, few are explored in hypertension. Examples include the following: phenolic compounds (butylated hydroxyanisole, butylated hydroxytoluene, and tert-butyl hydroquinone), isopropyl sulfur cyanogen compounds (sulforaphane), 1,2-mercapto-3-sulfur ketone derivatives (oltipraz), hydrogen peroxide compounds (hydrogen peroxide, isopropyl benzene hydrogen peroxide, and 4-butyl hydroperoxide), natural compounds from plants (curcumin, resveratrol, plumbagin, tanshinone, luteolin, oleanolic acid, etc.), and compounds that are rich in arsenic, selenium, trace elements, and heavy metal ions $[109,111]$. Registered drugs such as statins and metformin also have the ability to activate Nrf2 [91].

\subsection{Nrf2 Activators: Bardoxolone Methyl, Sulforaphane, and Dimethyl Fumarate}

Bardoxolone methyl (BM), a semisynthetic triterpenoid, is an Nrf2 activator and NF-kB pathway inhibitor, reducing OS, inflammation, and excessive RAS activation and promoting mitochondrial functions within the cells $[112,113]$. It has been proven that BM 
can be used as a powerful antiviral treatment option in hepatocyte cultures of hepatitis $B$ and $C$ viruses and also in herpes simplex virus type $1[114,115]$. Due to the current pandemic situation, studies regarding the use of BM in treating SARS-CoV-2 infections are still ongoing. There are currently two clinical phase III trials ongoing that investigate the safety of bardoxolone (CDD0-ME) therapy in patients with pulmonary hypertension: the Ranger trial (NCT03068130) and the CATALYST trial (NCT02657356). As we are at the inception of exploring the Nrf2-HTN relationship, it is not unexpected that we could not identify a specific clinical trial that explores therapy with Nrf2 in HTN.

Taking this into consideration, it is necessary to understand Nrf2's mediator role and the additional contribution of BM in the anti-inflammatory processes which take place throughout the body systems.

Sulforaphane (SFN), an isothiocyanate, is also a potent natural Nrf2 activator, which was first isolated from red cabbage and hoary cress and later from broccoli [116]. Its direct interaction with Keap1 allows Nrf2 to accumulate in the nucleus and to activate cytoprotective mechanisms in order to protect cells from ROS [117]. SFN has the ability to activate over 500 genes by means of the Nrf2/ARE signaling pathway. SFN is known as a natural compound that can induce phase II enzymes in vivo and in vitro. These enzymes play a role in inactivating and eliminating toxic substances accumulated during periods of OS within the vascular smooth muscle cells [118]. Senanayake et al. [119] studied the effect of SFN on SHRSP and Sprague Dawley (SD) rats. The research demonstrated that this Nrf2 activator decreased the three used parameters (systolic blood pressure, diastolic blood pressure, and mean arterial pressure) by $9 \%, 12 \%$, and 11\%, respectively, in SHRSP, while there was no effect on SD rats. Moderate activation of Nrf2 by SFN, which is basically a dietary factor, may emphasize the mild protective role of Nrf2 through a healthy diet, which could amplify the therapeutic benefits of this antioxidant-gene-modulated system.

Dimethyl fumarate (DMF) (Tecfidera), named after the earth smoke plant (Fumaria officinalis), is the methyl ester of fumaric acid. DMF has been reported to be one of the most potent Nrf2 activators, having antioxidant and anti-inflammatory properties [92]. This drug was approved in 2013 by the US Food and Drug Administration (FDA) as first-line treatment of relapsing-remitting multiple sclerosis [120] and in 2017 was approved by the European Medicines Agency (EMA) for the treatment of moderate-to-severe chronic plaque psoriasis [121].

DMF exerts potential neuroprotective, immunomodulating, antifibrotic, and radiosensitizing activities, which are dependent on Nrf2 antioxidant pathways. After oral administration, DMF is converted into its active metabolite monomethyl fumarate (MMF). MMF reacts with C151 in Keap1, thereby activating Nrf2 which subsequently translocates to the nucleus and binds to the AREs. This induces the expression of a number of cytoprotective genes, including NAD(P)H quinone oxidoreductase 1 (NQO1), sulfiredoxin 1 (Srxn1), heme oxygenase-1 (HO1, HMOX1), superoxide dismutase 1 (SOD1), gamma-glutamylcysteine synthetase (gamma-GCS), thioredoxin reductase-1 (TXNRD1), GST, and glutamate-cysteine ligase catalytic subunit (Gclc). It increases the synthesis of the antioxidant glutathione (GSH), and via inhibition of the NF-kB-mediated pathway, DMF modulates the production of certain cytokines [120]. Additionally, DMF activates the Nrf2/Keap1 pathway by S-alkylating Keap1 and by forcing BACH1, an Nrf2 inhibitor, to leave the nucleus [122].

Little attention has been given to the relation between DMF and CVDs, especially HTN. Experimental studies show that DMF reduces inflammation, oxidative damage, and fibrosis in mouse models of pulmonary arterial hypertension [123] and can attenuate aberrant remodeling after acute vascular injury in rodent carotid arteries [124]. Hsu et al. [125] studied male rats which were exposed prenatally to dexamethasone and postnatally to a diet rich in fats in order to develop HTN. After maternal DMF therapy in offspring, programmed HTN was prevented from developing. Via AKT/Nrf2 pathway, DMF reduces ROS generation and stimulates the expression of antioxidative genes regulated by Nrf2, having a protective role in pulmonary HTN or in diabetic cardiomyopathy [126]. Other researchers noted that fumaric acid and succinic acid may treat gestational hypertension by 
downregulating the expression of ten-eleven translocation 1 (TET1) and calcium-activated potassium channel subunit $\beta 1$ (KCNMB1) [127].

Although DMF demonstrated efficacy in diverse clinical trials in other diseases, hypertension-related studies failed to show therapeutic efficacy and were dropped, terminated, or withdrawn. A double-blinded, placebo-controlled study of DMF (NCT02981082) in systemic sclerosis-pulmonary hypertension (SSc-PAH) patients was terminated due to low recruitment numbers. In a small-size pilot study, patients with pulmonary arterial hypertension-associated systemic sclerosis tolerated DMF poorly and did not provide power to suggest efficacy. Still, authors suggest that Nrf2 remains a valid therapeutic target and should be tested in future trials by using better Nrf2 agonists [128].

Considering this emerging evidence, we may consider that fumaric acid esters might be beneficial for patients with vascular diseases [129]; however, more research that could expand the treatment area of DMF to other diseases such as hypertension, with clinical utility and favorable safety profiles, is desired.

\subsection{Natural Nrf2 Activators}

A myriad of ingredients that are used daily and have the ability to promote the nuclear translocation of Nrf2 are reported in Table 1. Among these, spices were demonstrated to have potential as natural Nrf2 pathway activators that can be used in disorders caused by OS $[130,131]$.

Table 1. Salient effects of natural Nrf2 activators. Kelch-like ECH-associated protein 1 (Keap1); nuclear factor erythroid factor 2-related factor 2 (Nrf2); glycogen synthase kinase-3 (GSK-3); malondialdehyde (MDA); superoxide dismutase (SOD); nuclear factor kappa-light-chain-enhancer of activated B cells (NF-kB); heme oxygenase-1 (HO-1); plasma glutathione peroxidase (GSH-Px).

\begin{tabular}{|c|c|c|c|c|}
\hline $\begin{array}{c}\text { Authors and } \\
\text { Ref. }\end{array}$ & $\begin{array}{l}\text { Natural } \\
\text { Compound }\end{array}$ & $\begin{array}{l}\text { Organic } \\
\text { Compound }\end{array}$ & $\begin{array}{c}\text { Species and/or Cells } \\
\text { Researched }\end{array}$ & Meaningful Findings \\
\hline Kim et al. [132] & Pepper & Methysticin & $\begin{array}{l}\text { Murine cell cultures } \\
\text { murine RAW } 264.7 \text { cell } \\
\text { line }\end{array}$ & $\begin{array}{l}\text { - Oxidation or alkylation of the } \\
\text { Keap1 proteins; } \\
\text { - } \quad \text { Inhibited binding of Nrf2 to } \\
\text { Keap1; } \\
\text { - } \quad \text { Phosphorylation of Nrf2 by } \\
\text { GSK-3 and subsequent } \\
\text { proteasomal degradation. }\end{array}$ \\
\hline Wafi et al. [133] & Turmeric & Curcumin & $\begin{array}{l}\text { Sixty male C57BL/ } 6 \\
\text { mice } 10 \text { weeks of age }\end{array}$ & $\begin{array}{ll}\text { - } & \text { Decreased MDA and SOD levels; } \\
\text { - } & \text { Suppression of the } \\
\text { Bax/Bcl-2-caspase-3 } \\
\text { pathway-mediated cell death; } \\
\text { - Diminished inflammation, } \\
\text { fibrosis, and hypertrophy. }\end{array}$ \\
\hline Ji et al. [134] & Ginger & $\begin{array}{c}\text { 6- } \\
\text { Dehydrogingerdione }\end{array}$ & $\begin{array}{l}\text { Human mesenchymal } \\
\text { stem cells }\end{array}$ & - Inhibition of NF- $\mathrm{kB}$ activation. \\
\hline $\begin{array}{l}\text { Mimura et al. } \\
{[135]}\end{array}$ & Rosemary & Carnosic acid & $\begin{array}{l}\text { U373MG cells (human } \\
\text { glioblastoma } \\
\text { astrocytoma cells) }\end{array}$ & - $\quad$ Keap1 inactivation. \\
\hline $\begin{array}{l}\text { Mohan Manu } \\
\text { et al. [136] }\end{array}$ & $\begin{array}{c}\text { Water hyssop } \\
\text { (Bacopa monnieri) }\end{array}$ & $\begin{array}{l}\text { Dammarane-type } \\
\text { triterpenoid } \\
\text { saponins }\end{array}$ & Adult male Wistar rats & $\begin{array}{l}\text { - } \quad \text { Restored expression of Nrf2, } \\
\text { NQO1 gene, and HO-1 followed } \\
\text { by increased antioxidant } \\
\text { enzymes and total glutathione } \\
\text { levels. }\end{array}$ \\
\hline
\end{tabular}


Table 1. Cont.

\begin{tabular}{|c|c|c|c|c|}
\hline $\begin{array}{l}\text { Authors and } \\
\text { Ref. }\end{array}$ & $\begin{array}{l}\text { Natural } \\
\text { Compound }\end{array}$ & $\begin{array}{l}\text { Organic } \\
\text { Compound }\end{array}$ & $\begin{array}{l}\text { Species and/or Cells } \\
\text { Researched }\end{array}$ & Meaningful Findings \\
\hline He et al. [137] & Thyme & Thymol & Zebrafish & $\begin{array}{l}\text { - Activated Nrf2/Keap1 pathway } \\
\text { (signifcant downregulation of } \\
\text { Keap1 expression and } \\
\text { upregulation of Nrf2 } \\
\text { expression). }\end{array}$ \\
\hline $\begin{array}{l}\text { Korenori et al. } \\
\text { [138] }\end{array}$ & Wasabi & Allyl isothiocyanate & $\begin{array}{l}\text { HepG2 (human } \\
\text { hepatoma) }\end{array}$ & $\begin{array}{l}\text { - Increased Keap1 modification } \\
\text { and diminished Nrf2 } \\
\text { degradation. }\end{array}$ \\
\hline $\begin{array}{l}\text { Kanlaya et al. } \\
\text { [139] }\end{array}$ & Green tea & Catechins & $\begin{array}{l}\text { Madin-Darby Canine } \\
\text { Kidney (MDCK) renal } \\
\text { tubular cells }\end{array}$ & $\begin{array}{l}\text { Increased antioxidative activity } \\
\text { of phase II enzymes. }\end{array}$ \\
\hline Paul et al. [140] & Ashwagandha & Triterpene lactones & $\begin{array}{l}\text { Coronary artery } \\
\text { occlusion in rats; } \\
\text { myocardial infarction } \\
\text { in rats }\end{array}$ & $\begin{array}{l}\text { - } \quad \text { Abrogated apoptosis in an } \\
\text { Nrf2-dependent manner; } \\
\text { - Increased phase II detoxification } \\
\text { enzymes. }\end{array}$ \\
\hline $\begin{array}{l}\text { Farkhondeh } \\
\text { et al. [141] }\end{array}$ & $\begin{array}{l}\text { Grapes, berries, } \\
\text { cranberries, nuts, } \\
\text { cocoa, and dark } \\
\text { chocolate }\end{array}$ & Resveratrol & $\begin{array}{l}\text { Adult male } \\
\text { Sprague-Dawley rats }\end{array}$ & $\begin{array}{l}\text { - Significant increase in GSH-Px } \\
\text { and SOD. }\end{array}$ \\
\hline Yang et al. [142] & $\begin{array}{l}\text { Tomatoes, } \\
\text { watermelons, red } \\
\text { carrots, grapefruits, } \\
\text { and papayas }\end{array}$ & Lycopene & $\begin{array}{l}\text { Human umbilical vein } \\
\text { cell line }\end{array}$ & $\begin{array}{l}\text { Inhibited NF- } \mathrm{KB} \text { nuclear } \\
\text { translocation and } \\
\text { transactivation. }\end{array}$ \\
\hline $\begin{array}{c}\text { Ramyaa et al. } \\
{[143]}\end{array}$ & $\begin{array}{l}\text { Apples, citrus fruits, } \\
\text { onions, green leafy } \\
\text { vegetables, honey }\end{array}$ & Quercetin & $\begin{array}{l}\text { Vero cells (African } \\
\text { green monkey kidney } \\
\text { epithelial cells) }\end{array}$ & - $\quad$ Nuclear Nrf2 translocation. \\
\hline
\end{tabular}

The experimental studies from Table 1 demonstrated that modulating natural products via Nrf2 pathways exerts beneficial antioxidant and anti-inflammatory effects $[132,137,140]$ in severe heart failure [133], in radiation-induced OS [134], in induced-cardiac stress [136], in renal impairment [139], in atherosclerosis [142], and in ochratoxin-induced toxicity [143] and also shows cytoprotective and antimicrobial properties [135]; cytoprotective and cancer chemopreventive effects [138]; and anti-inflammatory, antioxidant, hepatoprotective, neuroprotective, cardioprotective, renoprotective, antiobesity, antidiabetic, and anticancer effects [141] in other chronic diseases. Although the studies mentioned did not directly explore the effect of natural products in hypertension, the administration of these natural products leads to an Nrf2 response with subsequent activation of various protective pathways which can be linked to vascular protection.

These elements bring new scientific ideas and opportunities for future researchers to explore the association between these natural Nrf2 activators and HTN and the potential therapeutic targets of these natural Nrf2 activators in this disease.

\subsection{Other Therapeutic Options via Nrf2}

Antioxidants consist of a group of enzymes and molecules that counteract the harmful effects of ROS, and their main role is to keep a balance between these two systems, not to fully reduce oxidants, as they can also protect against pathogens [144]. Antioxidants can be produced endogenously, but their level might be inadequate. Therefore, the body needs additional exogenous sources of antioxidants, usually obtained from plants or drugs [145]. Plants have been used for their antioxidant properties for a long period of time, and 
they have proved to be able to effectively restore the balance between oxidation and antioxidation by removing ROS. They have few side effects, decrease ROS production, and stop oxidation by restricting the beginning and spreading of redox reactions [146].

Thioredoxin (Trx), glutaredoxin (Grx), and peroxiredoxin (Prx) belong to the thioredoxin family and can be found in all organisms. They function as antioxidants and are implicated in a myriad of CVDs, including HTN, atherosclerosis, ischemic heart diseases, and cardiac hypertrophy [147]. Ahsan et al.'s review article [148] emphasized how Trx serum levels can work as biomarkers in identifying cardiac adaptative reactions. Moreover, mesenchymal stem cells genetically modified to express Trx1 showed an increased ability to proliferate and divide into cardiomyocytes, smooth muscle cells, and endothelial cells, making them a potential therapy for cardiac failure $[149,150]$.

Inhibition of G6PD with a competitive inhibitor (6-aminonicotinamide) and with noncompetitive inhibitors (dehydroepiandrosterone and epiandrosterone) relaxes pulmonary arteries and precontracted aorta [151]. Dehydroepiandrosterone reduces pulmonary vascular resistance in pulmonary hypertensive rats [152], and researchers reported in humans that low levels of dehydroepiandrosterone sulfate are associated with increased severity of pulmonary hypertension [153]. A double-blind, randomized, placebo-controlled phase III study (NCT00581087) demonstrated that dehydroepiandrosterone improves pulmonary hypertension in chronic obstructive pulmonary disease (COPD) [154].

Additionally, researchers demonstrated that fructosamine 3-kinase (FN3K) triggers protein deglycation influencing Nrf2 activity. Sanghvi et al. [155] noted that FN3K is absent in certain cell stress such as cancer, and via Keap1, this can lead to extensively glycated Nrf2, which affects the ability of Nrf2 to bind proteins and interact with transcription cofactors. FN3K may represent a novel target of Nrf2 activity in cancer $[155,156]$. Even if the role of FN3K in arterial hypertension remains unclear, polymorphisms of the FN3K gene in patients with diabetes display a protective role against severe microangiopathy and macroangiopathy diabetes complications [157]. These data suggest that the FN3K-Nrf2 pathway is involved in different vascular alterations that may lead to hypertension and could represent a new therapeutic target.

Currently, multiple drugs are being used in the treatment of HTN, but they do not act via the Nrf2/Keap1 pathway. Among promising redox drugs for CVD therapy are antioxidants targeted against mitochondria (mitoQ) and Nrf2 activators (SFN, BM, DMF) [158]. There is strong evidence for resveratrol's antioxidant and anti-inflammatory properties and its beneficial role for patients with CVD, but it was found to be less effective in obese individuals [159]. Anyway, further research into resveratrol's properties and bioavailability is desirable.

As hypertension is a multifactorial disease, its clinical management usually includes lifestyle approaches and multiple-drug administration. So far, the efforts to find redoxbased therapies are still ongoing as there is still no evidence of a fully efficient Nrf2targeted drug in CVD, and implicitly HTN [8,109]. Further investigation and validation through clinical trials of a single Nrf2 activator via a certain pathway or a combination with another antioxidant are needed [150]. These results may provide enough scientific proof to implement a novel Nrf2-HTN therapeutic approach with practicability in clinical settings.

\section{Conclusions and Future Directions}

Arterial hypertension continues to remain an incremental and significant worldwide medical issue. The complex heterogeneity behind HTN also includes the imbalance and misregulation of OS factors. Even if HTN pathogenesis cannot be explained by only one mechanism, present-day data exhibit the deleterious effects of enhanced OS activity and excessive ROS products which perpetuate endothelial dysfunction and hypertension via different pathways. Nonetheless, research continuously brings us new molecules and transcriptional factors such as Nrf2, which in addition to its involvement in cardiovascular pathogenesis holds potential as a novel therapeutic approach in chronic diseases such as HTN. Preclinical studies support the anti-OS and anti-inflammatory effects of Nrf2 in 
HTN through regulation via various pathways. The pharmaceutical modulation of Nrf2 activity using natural and synthetic compounds enhances cell survival and sets in motion the endogenous defense antioxidant system. Biopharmaceutical companies are currently working on developing new drugs that target the Keap1-Nrf2 system, being challenged however by off-target effects and lack of a precise monitoring panel.

These results should encourage scientists to continue their research in this field. We hope for new discoveries which could help further demonstrate the key role of Nrf2 in HTN and its potential as a novel therapeutic target. Therefore, more research on this subject is essential for translating the OS concept into clinical practice.

Author Contributions: Conceptualization, D.M.T., A.G.A., M.A.M. and M.F.; methodology, C.F.C. and C.C.T.; software, I.T. and A.G.A.; validation, D.M.T., I.L.S. and M.A.M.; formal analysis, M.F.; investigation, I.T., A.G.A., C.F.C., C.C.T. and I.L.S.; resources, I.T.; data curation, D.M.T.; writingoriginal draft preparation, M.A.M. and I.L.S.; writing-review and editing I.T.; visualization, C.F.C.; supervision, C.C.T.; project administration, D.M.T.; funding acquisition, A.G.A. All authors have read and agreed to the published version of the manuscript.

Funding: This research received no external funding.

Conflicts of Interest: The authors declare no conflict of interest.

\section{References}

1. Williams, B.; Mancia, G.; Spiering, W.; Rosei, E.A.; Azizi, M.; Burnier, M.; Clement, D.L.; Coca, A.; De Simone, G.; Dominiczak, A.; et al. 2018 ESC/ESH Guidelines for Themanagement of Arterial Hypertension: The Task Force for the management of arterial hypertension of the European Society of Cardiology (ESC) and the European Society of Hypertension (ESH). Eur. Heart J. 2018, 39, 3021-3104. [CrossRef]

2. Zhou, B.; Carrillo-Larco, R.M.; Danaei, G.; Riley, L.M.; Paciorek, C.J.; Stevens, G.A.; Gregg, E.W.; Bennett, J.E.; Solomon, B.; Singleton, R.K.; et al. Worldwide trends in hypertension prevalence and progress in treatment and control from 1990 to 2019: A pooled analysis of 1201 population-representative studies with 104 million participants. Lancet 2021, 398, 957-980. [CrossRef]

3. Batiha, G.E.-S.; Gari, A.; Elshony, N.; Shaheen, H.M.; Abubakar, M.B.; Adeyemi, S.B.; Al-kuraishy, H.M. Hypertension and its management in COVID-19 patients: The assorted view. Int. J. Cardiol. Cardiovasc. Risk Prev. 2021, 11, 200121. [CrossRef]

4. Chen, G.; Li, X.; Gong, Z.; Xia, H.; Wang, Y.; Wang, X.; Huang, Y.; Barajas-Martinez, H.; Hu, D. Hypertension as a sequela in patients of SARS-CoV-2 infection. PLoS ONE 2021, 16, e0250815. [CrossRef]

5. Savoia, C.; Volpe, M.; Kreutz, R. Hypertension, a moving target in COVID-19: Current views and perspectives. Circ. Res. 2021, 128, 1062-1079. [CrossRef]

6. Muhamad, S.A.; Ugusman, A.; Kumar, J.; Skiba, D.; Hamid, A.A.; Aminuddin, A. COVID-19 and Hypertension: The What, the Why, and the How. Front. Physiol. 2021, 12, 1-11. [CrossRef]

7. Patrick, D.M.; Van Beusecum, J.P.; Kirabo, A. The role of inflammation in hypertension: Novel concepts. Curr. Opin. Physiol. 2021, 19, 92-98. [CrossRef]

8. Griendling, K.K.; Camargo, L.L.; Rios, F.J.; Alves-Lopes, R.; Montezano, A.C.; Touyz, R.M. Oxidative Stress and Hypertension. Circ. Res. 2021, 128, 993-1020. [CrossRef]

9. Janczura, M.; Rosa, R.; Dropinski, J.; Gielicz, A.; Stanisz, A.; Kotula-Horowitz, K.; Domagala, T. The associations of perceived and oxidative stress with hypertension in a cohort of police officers. Diabetes Metab. Syndr. Obes. 2021, 14, 1783-1797. [CrossRef]

10. Touyz, R.M.; Rios, F.J.; Alves-Lopes, R.; Neves, K.B.; Camargo, L.L.; Montezano, A.C. Oxidative Stress: A Unifying Paradigm in Hypertension. Can. J. Cardiol. 2020, 36, 659-670. [CrossRef]

11. Theofilis, P.; Sagris, M.; Oikonomou, E.; Antonopoulos, A.S.; Siasos, G.; Tsioufis, C.; Tousoulis, D. Inflammatory mechanisms contributing to endothelial dysfunction. Biomedicines 2021, 9, 781. [CrossRef]

12. Chaudhary, P.; Pandey, A.; Azad, C.S.; Tia, N.; Singh, M.; Gambhir, I.S. Association of oxidative stress and endothelial dysfunction in hypertension. Anal. Biochem. 2020, 590, 113535. [CrossRef]

13. Forman, H.J.; Zhang, H. Targeting oxidative stress in disease: Promise and limitations of antioxidant therapy. Nat. Rev. Drug Discov. 2021, 20, 689-709. [CrossRef]

14. Serra, A.J.; Pinto, J.R.; Prokić, M.D.; Arsa, G.; Vasconsuelo, A. Oxidative Stress in Muscle Diseases: Current and Future Therapy 2019. Oxid. Med. Cell. Longev. 2020, 2020, 4-7. [CrossRef]

15. Sies, H. Oxidative eustress: On constant alert for redox homeostasis. Redox Biol. 2021, 41, 101867. [CrossRef]

16. Qiu, D.; Wu, J.; Li, M.; Wang, L.; Zhu, X.; Chen, Y. Impaction of factors associated with oxidative stress on the pathogenesis of gestational hypertension and preeclampsia: A Chinese patients based study. Medicine 2021, 100, e23666. [CrossRef]

17. Sharifi-Rad, M.; Anil Kumar, N.V.; Zucca, P.; Varoni, E.M.; Dini, L.; Panzarini, E.; Rajkovic, J.; Tsouh Fokou, P.V.; Azzini, E.; Peluso, I.; et al. Lifestyle, Oxidative Stress, and Antioxidants: Back and Forth in the Pathophysiology of Chronic Diseases. Front. Physiol. 2020, 11, 1-21. [CrossRef] 
18. Snezhkina, A.V.; Kudryavtseva, A.V.; Kardymon, O.L.; Savvateeva, M.V.; Melnikova, N.V.; Krasnov, G.S.; Dmitriev, A.A. ROS generation and antioxidant defense systems in normal and malignant cells. Oxid. Med. Cell. Longev. 2020, $2019,6175804$. [CrossRef]

19. Liu, Q.Q.; Ren, K.; Liu, S.H.; Li, W.M.; Huang, C.J.; Yang, X.H. MicroRNA-140-5p aggravates hypertension and oxidative stress of atherosclerosis via targeting Nrf2 and Sirt2. Int. J. Mol. Med. 2019, 43, 839-849. [CrossRef]

20. Masi, S.; Georgiopoulos, G.; Chiriacò, M.; Grassi, G.; Seravalle, G.; Savoia, C.; Volpe, M.; Taddei, S.; Rizzoni, D.; Virdis, A. The importance of endothelial dysfunction in resistance artery remodelling and cardiovascular risk. Cardiovasc. Res. 2020, 116, 429-437. [CrossRef]

21. Pinheiro, L.C.; Oliveira-Paula, G.H. Sources and Effects of Oxidative Stress in Hypertension. Curr. Hypertens. Rev. 2019, 16, 166-180. [CrossRef] [PubMed]

22. Sousa, T.; Reina-Couto, M.; Gomes, P. Role of Oxidative Stress in the Pathophysiology of Arterial Hypertension and Heart Failure In Oxidative Stress in Heart Diseases; Chakraborti, S., Dhalla, N.S., Ganguly, N.K., Dikshit, M., Eds.; Springer: Singapore, 2019; pp. 509-537. ISBN 978-981-13-8273-4. [CrossRef]

23. Wu, Y.; Ding, Y.; Ramprasath, T.; Zou, M.H. Oxidative Stress, GTPCH1, and Endothelial Nitric Oxide Synthase Uncoupling in Hypertension. Antioxid. Redox Signal. 2021, 34, 750-764. [CrossRef] [PubMed]

24. Rudyk, O.; Aaronson, P.I. Redox Regulation, Oxidative Stress, and Inflammation in Group 3 Pulmonary Hypertension. Adv. Exp. Med. Biol. 2021, 1303, 209-241. [CrossRef] [PubMed]

25. Incalza, M.A.; D'Oria, R.; Natalicchio, A.; Perrini, S.; Laviola, L.; Giorgino, F. Oxidative stress and reactive oxygen species in endothelial dysfunction associated with cardiovascular and metabolic diseases. Vascul. Pharmacol. 2018, 100, 1-19. [CrossRef]

26. Narasimhan, M.; Rajasekaran, N.S. Exercise, Nrf2 and antioxidant signaling in cardiac aging. Front. Physiol. 2016, 7, 1-8. [CrossRef] [PubMed]

27. Powers, S.K.; Deminice, R.; Ozdemir, M.; Yoshihara, T.; Bomkamp, M.P.; Hyatt, H. Exercise-induced oxidative stress: Friend or foe? J. Sport Health Sci. 2020, 9, 415-425. [CrossRef] [PubMed]

28. Li, H.; Zhou, X.; Huang, Y.; Liao, B.; Cheng, L.; Ren, B. Reactive Oxygen Species in Pathogen Clearance: The Killing Mechanisms, the Adaption Response, and the Side Effects. Front. Microbiol. 2021, 11, 3610. [CrossRef]

29. Maldonado, E.; Rojas, D.A.; Morales, S.; Miralles, V.; Solari, A. Dual and Opposite Roles of Reactive Oxygen Species (ROS) in Chagas Disease: Beneficial on the Pathogen and Harmful on the Host. Oxid. Med. Cell. Longev. 2020, 2020, 8867701. [CrossRef]

30. Di Meo, S.; Reed, T.T.; Venditti, P.; Victor, V.M. Role of ROS and RNS Sources in Physiological and Pathological Conditions. Oxid. Med. Cell. Longev. 2016, 2016, 1245049. [CrossRef]

31. D’Oria, R.; Schipani, R.; Leonardini, A.; Natalicchio, A.; Perrini, S.; Cignarelli, A.; Laviola, L.; Giorgino, F. The Role of Oxidative Stress in Cardiac Disease: From Physiological Response to Injury Factor. Oxid. Med. Cell. Longev. 2020, 2020, 5732956. [CrossRef]

32. Casas, A.I.; Dao, V.T.-V.; Daiber, A.; Maghzal, G.J.; Di Lisa, F.; Kaludercic, N.; Leach, S.; Cuadrado, A.; Jaquet, V.; Seredenina, T.; et al. Reactive Oxygen-Related Diseases: Therapeutic Targets and Emerging Clinical Indications. Antioxid. Redox Signal. 2015, 23, 1171-1185. [CrossRef] [PubMed]

33. Dubois-Deruy, E.; Peugnet, V.; Turkieh, A.; Pinet, F. Oxidative Stress in Cardiovascular Diseases. Antioxidants 2020, 9 , 864. [CrossRef] [PubMed]

34. Farah, C.; Michel, L.Y.M.; Balligand, J.-L. Nitric oxide signalling in cardiovascular health and disease. Nat. Rev. Cardiol. 2018, 15, 292-316. [CrossRef] [PubMed]

35. Tejero, J.; Shiva, S.; Gladwin, M.T. Sources of vascular nitric oxide and reactive oxygen species and their regulation. Physiol. Rev. 2019, 99, 311-379. [CrossRef]

36. Kosutova, M.; Pechanova, O.; Barta, A.; Franova, S.; Cebova, M. Different adaptive NO-dependent Mechanisms in Normal and Hypertensive Conditions. Molecules 2019, 24, 1682. [CrossRef]

37. Costa, E.D.; Rezende, B.A.; Cortes, S.F.; Lemos, V.S. Neuronal nitric oxide synthase in vascular physiology and diseases. Front. Physiol. 2016, 7, 1-8. [CrossRef]

38. Bondonno, C.P.; Croft, K.D.; Hodgson, J.M. Dietary Nitrate, Nitric Oxide, and Cardiovascular Health. Crit. Rev. Food Sci. Nutr. 2016, 56, 2036-2052. [CrossRef]

39. Mónica, F.Z.; Bian, K.; Murad, F. Chapter One-The Endothelium-Dependent Nitric Oxide-cGMP Pathway. In Endothelium; Khalil, R.A., Ed.; Academic Press: Cambridge, MA, USA, 2016; Volume 77, pp. 1-27. ISBN 1054-3589. [CrossRef]

40. Gao, L.; Siu, K.L.; Chalupsky, K.; Nguyen, A.; Chen, P.; Weintraub, N.L.; Galis, Z.; Cai, H. Role of Uncoupled eNOS in Abdominal Aortic Aneurysm Formation: Treatment with Folic Acid. Hypertension 2012, 59, 158-166. [CrossRef]

41. Fleming, I. Chapter 23-NO Signaling Defects in Hypertension. In Nitric Oxide: Biology and Pathobiology, 3rd ed.; Ignarro, L.J., Freeman, B.A., Eds.; Academic Press: Cambridge, MA, USA, 2017; pp. 301-311. ISBN 978-0-12-804273-1. [CrossRef]

42. Higashi, Y.; Sasaki, S.; Nakagawa, K.; Fukuda, Y.; Matsuura, H.; Oshima, T.; Chayama, K. Tetrahydrobiopterin enhances forearm vascular response to acetylcholine in both normotensive and hypertensive individuals. Am. J. Hypertens. 2002, 15, 326-332. [CrossRef]

43. Zhang, Y.; Wong, H.S. Are mitochondria the main contributor of reactive oxygen species in cells. J. Exp. Biol. 2021, 224, jeb221606. [CrossRef]

44. Xin, T.; Lv, W.; Liu, D.; Jing, Y.; Hu, F. Opa1 Reduces Hypoxia-Induced Cardiomyocyte Death by Improving Mitochondrial Quality Control. Front. Cell Dev. Biol. 2020, 8, 1-13. [CrossRef] [PubMed] 
45. Dikalov, S.I.; Dikalova, A.E. Contribution of mitochondrial oxidative stress to hypertension. Curr. Opin. Nephrol. Hypertens. 2016, 25, 73. [CrossRef] [PubMed]

46. Tirichen, H.; Yaigoub, H.; Xu, W.; Wu, C.; Li, R.; Li, Y. Mitochondrial Reactive Oxygen Species and Their Contribution in Chronic Kidney Disease Progression Through Oxidative Stress. Front. Physiol. 2021, 12, 1-12. [CrossRef]

47. Togliatto, G.; Lombardo, G.; Brizzi, M.F. The future challenge of reactive oxygen species (ROS) in hypertension: From bench to bed side. Int. J. Mol. Sci. 2017, 18, 1988. [CrossRef] [PubMed]

48. Dikalov, S.I.; Nazarewicz, R.R. Angiotensin II-induced production of mitochondrial reactive oxygen species: Potential mechanisms and relevance for cardiovascular disease. Antioxid. Redox Signal. 2013, 19, 1085-1094. [CrossRef]

49. García-Navas, R.; Liceras-Boillos, P.; Gómez, C.; Baltanás, F.C.; Calzada, N.; Nuevo-Tapioles, C.; Cuezva, J.M.; Santos, E. Critical requirement of SOS1 RAS-GEF function for mitochondrial dynamics, metabolism, and redox homeostasis. Oncogene 2021, 40, 4538-4551. [CrossRef]

50. Kasai, S.; Shimizu, S.; Tatara, Y.; Mimura, J.; Itoh, K. Regulation of Nrf2 by Mitochondrial Reactive Oxygen Species in Physiology and Pathology. Biomolecules 2020, 10, 320. [CrossRef]

51. Emmerson, A.; Trevelin, S.C.; Mongue-Din, H.; Becker, P.D.; Ortiz, C.; Smyth, L.A.; Peng, Q.; Elgueta, R.; Sawyer, G.; Ivetic, A.; et al. Nox 2 in regulatory T cells promotes angiotensin II-induced cardiovascular remodeling. J. Clin. Investig. 2018, 128, 3088-3101. [CrossRef]

52. Hashad, A.M.; Sancho, M.; Brett, S.E.; Welsh, D.G. Reactive Oxygen Species Mediate the Suppression of Arterial Smooth Muscle T-type Ca2+ Channels by Angiotensin II. Sci. Rep. 2018, 8, 1-11. [CrossRef]

53. Gray, S.P.; Shah, A.M.; Smyrnias, I. NADPH oxidase 4 and its role in the cardiovascular system. Vasc. Biol. 2019, 1, H59-H66. [CrossRef]

54. Birk, M.; Baum, E.; Zadeh, J.K.; Manicam, C.; Pfeiffer, N.; Patzak, A.; Helmstädter, J.; Steven, S.; Kuntic, M.; Daiber, A.; et al Angiotensin ii induces oxidative stress and endothelial dysfunction in mouse ophthalmic arteries via involvement of at 1 receptors and nox2. Antioxidants 2021, 10, 1238. [CrossRef] [PubMed]

55. Zhang, Y.; Murugesan, P.; Huang, K.; Cai, H. NADPH oxidases and oxidase crosstalk in cardiovascular diseases: Novel therapeutic targets. Nat. Rev. Cardiol. 2020, 17, 170-194. [CrossRef]

56. Harrison, C.B.; Trevelin, S.C.; Richards, D.A.; Santos, C.X.C.; Sawyer, G.; Markovinovic, A.; Zhang, X.; Zhang, M.; Brewer, A.C.; Yin, X.; et al. Fibroblast Nox2 (NADPH Oxidase-2) Regulates ANG II (Angiotensin II)-Induced Vascular Remodeling and Hypertension via Paracrine Signaling to Vascular Smooth Muscle Cells. Arterioscler. Thromb. Vasc. Biol. 2021, 2, 698-710. [CrossRef] [PubMed]

57. Akram, M.; Ali Shah, S.M.; Munir, N.; Daniyal, M.; Tahir, I.M.; Mahmood, Z.; Irshad, M.; Akhlaq, M.; Sultana, S.; Zainab, R. Hexose monophosphate shunt, the role of its metabolites and associated disorders: A review. J. Cell. Physiol. 2019, 9, 14473-14482. [CrossRef] [PubMed]

58. Song, M.-Y.; Lee, D.-Y.; Chun, K.-S.; Kim, E.-H. The Role of NRF2/KEAP1 Signaling Pathway in Cancer Metabolism. Int. J. Mol. Sci. 2021, 22, 4376. [CrossRef]

59. Hashimoto, R.; Gupte, S. Pentose Shunt, Glucose-6-Phosphate Dehydrogenase, NADPH Redox, and Stem Cells in Pulmonary Hypertension. Adv. Exp. Med. Biol. 2017, 967, 47-55. [CrossRef]

60. Packer, M. Uric Acid Is a Biomarker of Oxidative Stress in the Failing Heart: Lessons Learned from Trials With Allopurinol and SGLT2 Inhibitors. J. Card. Fail. 2020, 26, 977-984. [CrossRef] [PubMed]

61. Mervaala, E.; Cheng, Z.; Tikkanen, I.; Lapatto, R.; Nurminen, K.; Vapaatalo, H.; Müller, D.; Fiebeler, A.; Ganten, U.; Ganten, D.; et al. Endothelial Dysfunction and Xanthine Oxidoreductase Activity in Rats With Human Renin and Angiotensinogen Genes. Hypertension 2001, 37, 414-418. [CrossRef]

62. Battelli, M.G.; Polito, L.; Bolognesi, A. Xanthine oxidoreductase in atherosclerosis pathogenesis: Not only oxidative stress. Atherosclerosis 2014, 237, 562-567. [CrossRef]

63. Moi, P.; Chan, K.; Asunis, I.; Cao, A.; Kan, Y.W. Isolation of NF-E2-related factor 2 (Nrf2), a NF-E2-like basic leucine zipper transcriptional activator that binds to the tandem NF-E2/AP1 repeat of the beta-globin locus control region. Proc. Natl. Acad. Sci. USA 1994, 91, 9926-9930. [CrossRef]

64. Liou, S.F.; Nguyen, T.T.N.; Hsu, J.H.; Sulistyowati, E.; Huang, S.E.; Wu, B.N.; Lin, M.C.; Yeh, J.L. The preventive effects of xanthohumol on vascular calcification induced by vitamin D3 plus nicotine. Antioxidants 2020, 9, 956. [CrossRef] [PubMed]

65. Sarutipaiboon, I.; Settasatian, N.; Komanasin, N.; Kukongwiriyapan, U.; Sawanyawisuth, K.; Intharaphet, P.; Senthong, V.; Settasatian, C. Association of Genetic Variations in NRF2, NQO1, HMOX1, and MT with Severity of Coronary Artery Disease and Related Risk Factors. Cardiovasc. Toxicol. 2020, 20, 176-189. [CrossRef]

66. Yagishita, Y.; Gatbonton-schwager, T.N.; McCallum, M.L.; Kensler, T.W. Current landscape of NRF2 biomarkers in clinical trials. Antioxidants 2020, 9, 716. [CrossRef]

67. Zgorzynska, E.; Dziedzic, B.; Walczewska, A. An overview of the nrf2/are pathway and its role in neurodegenerative diseases. Int. J. Mol. Sci. 2021, 22, 9592. [CrossRef] [PubMed]

68. Mata, A.; Cadenas, S. The Antioxidant Transcription Factor Nrf2 in Cardiac Ischemia-Reperfusion Injury. Int. J. Mol. Sci. 2021, 22, 11939. [CrossRef]

69. Tan, X.; Jiao, P.L.; Sun, J.C.; Wang, W.; Ye, P.; Wang, Y.K.; Leng, Y.Q.; Wang, W.Z. $\beta$-Arrestin1 Reduces Oxidative Stress via Nrf2 Activation in the Rostral Ventrolateral Medulla in Hypertension. Front. Neurosci. 2021, 15, 1-12. [CrossRef] [PubMed] 
70. Shin, J.M.; Lee, K.-M.; Lee, H.J.; Yun, J.H.; Nho, C.W. Physalin A regulates the Nrf2 pathway through ERK and p38 for induction of detoxifying enzymes. BMC Complement. Altern. Med. 2019, 19, 101. [CrossRef]

71. Koundouros, N.; Poulogiannis, G. Phosphoinositide 3-Kinase/Akt Signaling and Redox Metabolism in Cancer. Front. Oncol. 2018, 8, 160. [CrossRef]

72. Matzinger, M.; Fischhuber, K.; Pölöske, D.; Mechtler, K.; Heiss, E.H. AMPK leads to phosphorylation of the transcription factor Nrf2, tuning transactivation of selected target genes. Redox Biol. 2020, 29, 101393. [CrossRef]

73. Liu, H.; Johnston, L.J.; Wang, F.; Ma, X. Triggers for the nrf2/are signaling pathway and its nutritional regulation: Potential therapeutic applications of ulcerative colitis. Int. J. Mol. Sci. 2021, 22, 11411. [CrossRef]

74. Silva-Islas, C.A.; Maldonado, P.D. Canonical and non-canonical mechanisms of Nrf2 activation. Pharmacol. Res. 2018, 134, 92-99. [CrossRef] [PubMed]

75. Baird, L.; Yamamoto, M. The Molecular Mechanisms Regulating the KEAP1-NRF2 Pathway. Mol. Cell. Biol. 2020, 40, e00099-20. [CrossRef] [PubMed]

76. Liu, T.; Lv, Y.-F.; Zhao, J.-L.; You, Q.-D.; Jiang, Z.-Y. Regulation of Nrf2 by phosphorylation: Consequences for biological function and therapeutic implications. Free Radic. Biol. Med. 2021, 168, 129-141. [CrossRef] [PubMed]

77. Chen, B.; Lu, Y.; Chen, Y.; Cheng, J. The role of Nrf2 in oxidative stress-induced endothelial injuries. J. Endocrinol. 2015, 225, R83-R99. [CrossRef]

78. Zang, H.; Mathew, R.O.; Cui, T. The Dark Side of Nrf2 in the Heart. Front. Physiol. 2020, 11, 722. [CrossRef]

79. Kannan, S.; Muthusamy, V.R.; Whitehead, K.J.; Wang, L.; Gomes, A.V.; Litwin, S.E.; Kensler, T.W.; Abel, E.D.; Hoidal, J.R.; Rajasekaran, N.S. Nrf2 deficiency prevents reductive stress-induced hypertrophic cardiomyopathy. Cardiovasc. Res. 2013, 100, 63-73. [CrossRef]

80. Qin, Q.; Qu, C.; Niu, T.; Zang, H.; Qi, L.; Lyu, L.; Wang, X.; Nagarkatti, M.; Nagarkatti, P.; Janicki, J.S.; et al. Nrf2-Mediated Cardiac Maladaptive Remodeling and Dysfunction in a Setting of Autophagy Insufficiency. Hypertension 2016, 67, 107-117. [CrossRef]

81. Ooi, B.K.; Goh, B.H.; Yap, W.H. Oxidative stress in cardiovascular diseases: Involvement of Nrf2 antioxidant redox signaling in macrophage foam cells formation. Int. J. Mol. Sci. 2017, 18, 2336. [CrossRef]

82. Da Costa, R.M.; Rodrigues, D.; Pereira, C.A.; Silva, J.F.; Alves, J.V.; Lobato, N.S.; Tostes, R.C. Nrf2 as a potential mediator of cardiovascular risk in metabolic diseases. Front. Pharmacol. 2019, 10, 1-12. [CrossRef]

83. Karan, A.; Bhakkiyalakshmi, E.; Jayasuriya, R.; Sarada, D.V.L.; Ramkumar, K.M. The pivotal role of nuclear factor erythroid 2-related factor 2 in diabetes-induced endothelial dysfunction. Pharmacol. Res. 2020, 153, 104601. [CrossRef]

84. Behl, T.; Kaur, I.; Sehgal, A.; Sharma, E.; Kumar, A.; Grover, M.; Bungau, S. Unfolding Nrf2 in diabetes mellitus. Mol. Biol. Rep. 2021, 48, 927-939. [CrossRef] [PubMed]

85. Bayliak, M.M.; Abrat, O.B. Role of Nrf2 in Oxidative and Inflammatory Processes in Obesity and Metabolic Diseases BT-Nrf2 and its Modulation in Inflammation. In Nrf2 and Its Modulation in Inflammation; Deng, H., Ed.; Springer International Publishing: Cham, Switzerland, 2020; pp. 153-187. ISBN 978-3-030-44599-7. [CrossRef]

86. Li, S.; Eguchi, N.; Lau, H.; Ichii, H. The Role of the Nrf2 Signaling in Obesity and Insulin Resistance. Int. J. Mol. Sci. 2020, 21, 6973. [CrossRef] [PubMed]

87. Vasileva, L.V.; Savova, M.S.; Amirova, K.M.; Dinkova-Kostova, A.T.; Georgiev, M.I. Obesity and NRF2-mediated cytoprotection: Where is the missing link? Pharmacol. Res. 2020, 156, 104760. [CrossRef] [PubMed]

88. Cuadrado, A.; Manda, G.; Hassan, A.; Alcaraz, M.J.; Barbas, C.; Daiber, A.; Ghezzi, P.; León, R.; López, M.G.; Oliva, B.; et al. Transcription Factor NRF2 as a Therapeutic Target for Chronic Diseases: A Systems Medicine Approach. Pharmacol. Rev. 2018, 70, 348-383. [CrossRef]

89. McSweeney, S.R.; Warabi, E.; Siow, R.C.M. Nrf2 as an Endothelial Mechanosensitive Transcription Factor: Going With the Flow. Hypertension 2016, 67, 20-29. [CrossRef]

90. Polvani, S.; Tarocchi, M.; Galli, A. PPAR $\gamma$ and Oxidative Stress: Con $\beta$ ) Catenating NRF2 and FOXO. PPAR Res. 2012, $2012,641087$. [CrossRef]

91. Kvandová, M.; Majzúnová, M.; Dovinová, I. The role of PPAR $\gamma$ in cardiovascular diseases. Physiol. Res. 2016, 65, S343-S363. [CrossRef]

92. Dovinova, I.; Kvandova, M.; Balis, P.; Gresova, L.; Majzunova, M.; Horakova, L.; Chan, J.Y.H.; Barancik, M. The Role of Nrf2 and PPAR $\gamma$ in the Improvement of Oxidative Stress in Hypertension and Cardiovascular Diseases. Physiol. Res. 2020, 69, S541-S553. [CrossRef]

93. Mussbacher, M.; Salzmann, M.; Brostjan, C.; Hoesel, B.; Schoergenhofer, C.; Datler, H.; Hohensinner, P.; Basílio, J.; Petzelbauer, P.; Assinger, A.; et al. Cell Type-Specific Roles of NF-кB Linking Inflammation and Thrombosis. Front. Immunol. 2019, 10, 85. [CrossRef]

94. Giridharan, S.; Srinivasan, M. Mechanisms of NF-кB p65 and strategies for therapeutic manipulation. J. Inflamm. Res. 2018, 11, 407-419. [CrossRef]

95. Bhandari, R.; Khanna, G.; Kaushik, D.; Kuhad, A. Divulging the Intricacies of Crosstalk Between NF-Kb and Nrf2-Keap1 Pathway in Neurological Complications of COVID-19. Mol. Neurobiol. 2021, 58, 3347-3361. [CrossRef] [PubMed]

96. Farooqui, Z.; Mohammad, R.S.; Lokhandwala, M.F.; Banday, A.A. Nrf2 inhibition induces oxidative stress, renal inflammation and hypertension in mice. Clin. Exp. Hypertens. 2021, 43, 175-180. [CrossRef] [PubMed] 
97. Wang, C.; Luo, Z.; Carter, G.; Wellstein, A.; Jose, P.A.; Tomlinson, J.; Leiper, J.; Welch, W.J.; Wilcox, C.S.; Wang, D. NRF2 prevents hypertension, increased ADMA, microvascular oxidative stress, and dysfunction in mice with two weeks of ANG II infusion. Am. J. Physiol. Regul. Integr. Comp. Physiol. 2018, 314, R399-R406. [CrossRef]

98. Ahmed, S.M.U.; Luo, L.; Namani, A.; Wang, X.J.; Tang, X. Nrf2 signaling pathway: Pivotal roles in inflammation. Biochim. Biophys. Acta-Mol. Basis Dis. 2017, 1863, 585-597. [CrossRef] [PubMed]

99. Lopes, R.A.; Neves, K.B.; Tostes, R.C.; Montezano, A.C.; Touyz, R.M. Downregulation of Nuclear Factor Erythroid 2-Related Factor and Associated Antioxidant Genes Contributes to Redox-Sensitive Vascular Dysfunction in Hypertension. Hypertension 2015, 66, 1240-1250. [CrossRef] [PubMed]

100. Banday, A.A.; Lokhandwala, M.F. Transcription factor Nrf2 protects renal dopamine D1 receptor function during oxidative stress. Hypertension 2013, 62, 512-517. [CrossRef] [PubMed]

101. Kim, J.; Grotegut, C.A.; Wisler, J.W.; Li, T.; Mao, L.; Chen, M.; Chen, W.; Rosenberg, P.B.; Rockman, H.A.; Lefkowitz, R.J. $\beta$-arrestin 1 regulates $\beta 2$-adrenergic receptor-mediated skeletal muscle hypertrophy and contractility. Skelet. Muscle 2018, 8, 39. [CrossRef] [PubMed]

102. Pugh, D.; Gallacher, P.J.; Dhaun, N. Management of Hypertension in Chronic Kidney Disease. Drugs 2019, 79, 365-379. [CrossRef]

103. Gray, Z.; Tu, W.; Chertow, G.M.; Bhalla, V. Aldosterone sensitivity: An opportunity to explore the pathogenesis of hypertension Am. J. Physiol. Physiol. 2021, 320, F325-F335. [CrossRef]

104. Inoue, K.; Goldwater, D.; Allison, M.; Seeman, T.; Kestenbaum, B.R.; Watson, K.E. Serum Aldosterone Concentration, Blood Pressure, and Coronary Artery Calcium. Hypertension 2020, 76, 113-120. [CrossRef]

105. Ames, M.K.; Atkins, C.E.; Pitt, B. The renin-angiotensin-aldosterone system and its suppression. J. Vet. Intern. Med. 2019, 33, 363-382. [CrossRef] [PubMed]

106. Xiao, L.; Gao, L.; Lazartigues, E.; Zucker, I.H. Brain-selective overexpression of angiotensin-converting enzyme 2 attenuates sympathetic nerve activity and enhances baroreflex function in chronic heart failure. Hypertension 2011, 58, 1057-1065. [CrossRef] [PubMed]

107. Ma, A.; Gao, L.; Wafi, A.M.; Yu, L.; Rudebush, T.; Zhou, W.; Zucker, I.H. Overexpression of central ACE2 (angiotensin-converting enzyme 2) attenuates the pressor response to chronic central infusion of ang II (angiotensin II): A potential role for Nrf2 (nuclear factor [erythroid-derived 2]-like 2). Hypertension 2020, 2, 1514-1525. [CrossRef] [PubMed]

108. Satta, S.; Mahmoud, A.M.; Wilkinson, F.L.; Yvonne Alexander, M.; White, S.J. The Role of Nrf2 in Cardiovascular Function and Disease. Oxid. Med. Cell. Longev. 2017, 2017, 9237263. [CrossRef] [PubMed]

109. Robledinos-Antón, N.; Fernández-Ginés, R.; Manda, G.; Cuadrado, A. Activators and Inhibitors of NRF2: A Review of Their Potential for Clinical Development. Oxid. Med. Cell. Longev. 2019, 2019, 9372182. [CrossRef]

110. Kopacz, A.; Kloska, D.; Forman, H.J.; Jozkowicz, A.; Grochot-Przeczek, A. Beyond repression of Nrf2: An update on Keap1. Free Radic. Biol. Med. 2020, 157, 63-74. [CrossRef]

111. Tkachev, V.O.; Menshchikova, E.B.; Zenkov, N.K. Mechanism of the Nrf2/Keap1/ARE signaling system. Biochemistry 2011, 76, 407-422. [CrossRef]

112. Chin, M.P.; Bakris, G.L.; Block, G.A.; Chertow, G.M.; Goldsberry, A.; Inker, L.A.; Heerspink, H.J.L.; O'Grady, M.; Pergola, P.E.; Wanner, C.; et al. Bardoxolone Methyl Improves Kidney Function in Patients with Chronic Kidney Disease Stage 4 and Type 2 Diabetes: Post-Hoc Analyses from Bardoxolone Methyl Evaluation in Patients with Chronic Kidney Disease and Type 2 Diabetes Study. Am. J. Nephrol. 2018, 47, 40-47. [CrossRef]

113. Sun, Q.; Ye, F.; Liang, H.; Liu, H.; Li, C.; Lu, R.; Huang, B.; Zhao, L.; Tan, W.; Lai, L. Bardoxolone and bardoxolone methyl, two Nrf2 activators in clinical trials, inhibit SARS-CoV-2 replication and its 3C-like protease. Signal Transduct. Target. Ther. 2021, 6, 2020-2022. [CrossRef]

114. Nio, Y.; Sasai, M.; Akahori, Y.; Okamura, H.; Hasegawa, H.; Oshima, M.; Watashi, K.; Wakita, T.; Ryo, A.; Tanaka, Y.; et al. Bardoxolone methyl as a novel potent antiviral agent against hepatitis B and C viruses in human hepatocyte cell culture systems. Antivir. Res. 2019, 169, 104537. [CrossRef]

115. Cuadrado, A.; Pajares, M.; Benito, C.; Jiménez-Villegas, J.; Escoll, M.; Fernández-Ginés, R.; Garcia Yagüe, A.J.; Lastra, D.; Manda, G.; Rojo, A.I.; et al. Can Activation of NRF2 Be a Strategy against COVID-19? Trends Pharmacol. Sci. 2020, 41, 598-610. [CrossRef] [PubMed]

116. Yagishita, Y.; Fahey, J.W.; Dinkova-Kostova, A.T.; Kensler, T.W. Broccoli or sulforaphane: Is it the source or dose that matters? Molecules 2019, 24, 3593. [CrossRef] [PubMed]

117. Gwon, Y.; Oh, J.; Kim, J.S. Sulforaphane induces colorectal cancer cell proliferation through Nrf2 activation in a p53-dependent manner. Appl. Biol. Chem. 2020, 63, 86. [CrossRef]

118. Ruhee, R.T.; Suzuki, K. The integrative role of sulforaphane in preventing inflammation, oxidative stress and fatigue: A review of a potential protective phytochemical. Antioxidants 2020, 9, 521. [CrossRef]

119. Senanayake, G.V.K.; Banigesh, A.; Wu, L.; Lee, P.; Juurlink, B.H.J. The dietary phase 2 protein inducer sulforaphane can normalize the kidney epigenome and improve blood pressure in hypertensive rats. Am. J. Hypertens. 2012, 25, 229-235. [CrossRef]

120. Kim, S.; Chen, J.; Cheng, T.; Gindulyte, A.; He, J.; He, S.; Li, Q.; Shoemaker, B.A.; Thiessen, P.A.; Yu, B.; et al. PubChem in 2021: New data content and improved web interfaces. Nucleic Acids Res. 2021, 49, D1388-D1395. [CrossRef]

121. Blair, H.A. Dimethyl Fumarate: A Review in Moderate to Severe Plaque Psoriasis. Drugs 2018, 78, 123-130. [CrossRef] 
122. Lipton, S.; Satoh, T. Recent advances in understanding NRF2 as a druggable target: Development of pro-electrophilic and non-covalent NRF2 activators to overcome systemic side effects of electrophilic drugs like dimethyl fumarate. F1000Research $\mathbf{2 0 1 7}$ 6,1-10. [CrossRef]

123. Grzegorzewska, A.P.; Seta, F.; Han, R.; Czajka, C.A.; Makino, K.; Stawski, L.; Isenberg, J.S.; Browning, J.L.; Trojanowska, M. Dimethyl Fumarate ameliorates pulmonary arterial hypertension and lung fibrosis by targeting multiple pathways. Sci. Rep. 2017, 7, 41605. [CrossRef]

124. Oh, C.J.; Park, S.; Kim, J.-Y.; Kim, H.-J.; Jeoung, N.H.; Choi, Y.-K.; Go, Y.; Park, K.-G.; Lee, I.-K. Dimethylfumarate attenuates restenosis after acute vascular injury by cell-specific and Nrf2-dependent mechanisms. Redox Biol. 2014, 2, 855-864. [CrossRef]

125. Hsu, C.N.; Lin, Y.J.; Yu, H.R.; Lin, I.C.; Sheen, J.M.; Huang, L.T.; Tain, Y.L. Protection of male rat offspring against hypertension programmed by prenatal dexamethasone administration and postnatal high-fat diet with the Nrf2 activator dimethyl fumarate during pregnancy. Int. J. Mol. Sci. 2019, 20, 3957. [CrossRef]

126. Kuang, Y.; Zhang, Y.; Xiao, Z.; Xu, L.; Wang, P.; Ma, Q. Protective effect of dimethyl fumarate on oxidative damage and signaling in cardiomyocytes. Mol. Med. Rep. 2020, 22, 2783-2790. [CrossRef] [PubMed]

127. Zhou, Y.; Zhang, F.; Jiang, H.; Xu, D.; Deng, D. Fumaric acid and succinic acid treat gestational hypertension by downregulating the expression of KCNMB1 and TET1. Exp. Ther. Med. 2021, 22, 1072. [CrossRef] [PubMed]

128. Kong, K.; Koontz, D.; Morse, C.; Roth, E.; Domsic, R.T.; Simon, M.A.; Stratton, E.; Buchholz, C.; Tobin-Finch, K.; Simms, R.; et al A Pilot Study of Dimethyl Fumarate in Pulmonary Arterial Hypertension Associated with Systemic Sclerosis. J. Scleroderma Relat. Disord. 2021, 6, 242-246. [CrossRef] [PubMed]

129. Kourakis, S.; Timpani, C.A.; de Haan, J.B.; Gueven, N.; Fischer, D.; Rybalka, E. Dimethyl Fumarate and Its Esters: A Drug with Broad Clinical Utility? Pharmaceuticals 2020, 13, 306. [CrossRef]

130. Qader, M.; Xu, J.; Yang, Y.; Liu, Y.; Cao, S. Natural nrf2 activators from juices, wines, coffee, and cocoa. Beverages $2020,6,68$. [CrossRef]

131. Sengupta, S.; Bhattacharyya, D.; Kasle, G.; Karmakar, S.; Sahu, O.; Ganguly, A.; Addya, S.; Das Sarma, J. Potential Immunomodulatory Properties of Biologically Active Components of Spices Against SARS-CoV-2 and Pan $\beta$-Coronaviruses. Front. Cell. Infect. Microbiol. 2021, 11, 1-12. [CrossRef]

132. Kim, D.W.; Kim, M.J.; Shin, Y.; Jung, S.K.; Kim, Y.J. Green pepper (Piper nigrum 1.) extract suppresses oxidative stress and lps-induced inflammation via regulation of JNK signaling pathways. Appl. Sci. 2020, 10, 2519. [CrossRef]

133. Wafi, A.M.; Hong, J.; Rudebush, T.L.; Yu, L.; Hackfort, B.; Wang, H.; Schultz, H.D.; Zucker, I.H.; Gao, L. Curcumin improves exercise performance of mice with coronary artery ligation-induced HFrEF: Nrf2 and antioxidant mechanisms in skeletal muscle. J. Appl. Physiol. 2019, 126, 477-486. [CrossRef]

134. Ji, K.; Fang, L.; Zhao, H.; Li, Q.; Shi, Y.; Xu, C.; Wang, Y.; Du, L.; Wang, J.; Liu, Q. Ginger Oleoresin Alleviated $\gamma$-Ray IrradiationInduced Reactive Oxygen Species via the Nrf2 Protective Response in Human Mesenchymal Stem Cells. Oxid. Med. Cell. Longev. 2017, 2017, 1480294. [CrossRef]

135. Mimura, J.; Inose-Maruyama, A.; Taniuchi, S.; Kosaka, K.; Yoshida, H.; Yamazaki, H.; Kasai, S.; Harada, N.; Kaufman, R.J.; Oyadomari, S.; et al. Concomitant Nrf2- and ATF4-Activation by Carnosic Acid Cooperatively Induces Expression of Cytoprotective Genes. Int. J. Mol. Sci. 2019, 20, 1706. [CrossRef]

136. Mohan Manu, T.; Anand, T.; Sharath Babu, G.R.; Patil, M.M.; Khanum, F. Bacopa monniera extract mitigates isoproterenol-induced cardiac stress via Nrf2/Keap1/NQO1 mediated pathway. Arch. Physiol. Biochem. 2019, 1-11. [CrossRef]

137. He, T.; Li, X.; Wang, X.; Xu, X.; Yan, X.; Li, X.; Sun, S.; Dong, Y.; Ren, X.; Liu, X.; et al. Chemical composition and anti-oxidant potential on essential oils of Thymus quinquecostatus Celak. from Loess Plateau in China, regulating Nrf2/Keap1 signaling pathway in zebrafish. Sci. Rep. 2020, 10, 11280. [CrossRef]

138. Korenori, Y.; Tanigawa, S.; Kumamoto, T.; Qin, S.; Daikoku, Y.; Miyamori, K.; Nagai, M.; Hou, D.-X. Modulation of Nrf2/Keap1 system by Wasabi 6-methylthiohexyl isothiocyanate in ARE-mediated NQO1 expression. Mol. Nutr. Food Res. 2013, 57, 854-864 [CrossRef] [PubMed]

139. Kanlaya, R.; Khamchun, S.; Kapincharanon, C.; Thongboonkerd, V. Protective effect of epigallocatechin-3-gallate (EGCG) via Nrf2 pathway against oxalate-induced epithelial mesenchymal transition (EMT) of renal tubular cells. Sci. Rep. 2016, 6, 1-13. [CrossRef] [PubMed]

140. Paul, S.; Chakraborty, S.; Anand, U.; Dey, S.; Nandy, S.; Ghorai, M.; Saha, S.C.; Patil, M.T.; Kandimalla, R.; Proćków, J.; et al. Withania somnifera (L.) Dunal (Ashwagandha): A comprehensive review on ethnopharmacology, pharmacotherapeutics, biomedicinal and toxicological aspects. Biomed. Pharmacother. 2021, 143, 112175. [CrossRef] [PubMed]

141. Farkhondeh, T.; Folgado, S.L.; Pourbagher-Shahri, A.M.; Ashrafizadeh, M.; Samarghandian, S. The therapeutic effect of resveratrol: Focusing on the Nrf2 signaling pathway. Biomed. Pharmacother. 2020, 127, 110234. [CrossRef]

142. Yang, P.M.; Chen, H.Z.; Huang, Y.T.; Hsieh, C.W.; Wung, B.S. Lycopene inhibits NF-kB activation and adhesion molecule expression through Nrf2-mediated heme oxygenase-1 in endothelial cells. Int. J. Mol. Med. 2017, 39, 1533-1540. [CrossRef]

143. Ramyaa, P.; Padma, V.V. Ochratoxin-induced toxicity, oxidative stress and apoptosis ameliorated by quercetin-Modulation by Nrf2. Food Chem. Toxicol. 2013, 62, 205-216. [CrossRef]

144. Moussa, Z.; Judeh, Z.; Ahmed, S. Nonenzymatic Exogenous and Endogenous Antioxidants. In Free Radical Medicine and Biology; IntechOpen: London, UK, 2019; ISBN 978-1-78985-143-4. [CrossRef] 
145. Dias, T.R.; Martin-Hidalgo, D.; Silva, B.M.; Oliveira, P.F.; Alves, M.G. Endogenous and Exogenous Antioxidants As a Tool to Ameliorate Male Infertility Induced by Reactive Oxygen Species. Antioxid. Redox Signal. 2020, 33, 767-785. [CrossRef] [PubMed]

146. Chang, X.; Zhao, Z.; Zhang, W.; Liu, D.; Ma, C.; Zhang, T.; Meng, Q.; Yan, P.; Zou, L.; Zhang, M. Natural Antioxidants Improve the Vulnerability of Cardiomyocytes and Vascular Endothelial Cells under Stress Conditions: A Focus on Mitochondrial Quality Control. Oxid. Med. Cell. Longev. 2021, 2021, 6620677. [CrossRef]

147. Seco-Cervera, M.; González-Cabo, P.; Pallardó, F.V.; Romá-Mateo, C.; García-Giménez, J.L. Thioredoxin and glutaredoxin systems as potential targets for the development of new treatments in Friedreich's ataxia. Antioxidants 2020, 9, 1257. [CrossRef] [PubMed]

148. Ahsan, M.K.; Lekli, I.; Ray, D.; Yodoi, J.; Das, D.K. Redox regulation of cell survival by the thioredoxin superfamily: An implication of redox gene therapy in the heart. Antioxid. Redox Signal. 2009, 11, 2741-2758. [CrossRef]

149. Suresh, S.C.; Selvaraju, V.; Thirunavukkarasu, M.; Goldman, J.W.; Husain, A.; Alexander Palesty, J.; Sanchez, J.A.; McFadden, D.W.; Maulik, N. Thioredoxin-1 (Trx1) engineered mesenchymal stem cell therapy increased pro-angiogenic factors, reduced fibrosis and improved heart function in the infarcted rat myocardium. Int. J. Cardiol. 2015, 201, 517-528. [CrossRef]

150. Cuadrado, A.; Rojo, A.I.; Wells, G.; Hayes, J.D.; Cousin, S.P.; Rumsey, W.L.; Attucks, O.C.; Franklin, S.; Levonen, A.-L.; Kensler, T.W.; et al. Therapeutic targeting of the NRF2 and KEAP1 partnership in chronic diseases. Nat. Rev. Drug Discov. 2019, 18, 295-317. [CrossRef]

151. Gupte, S.A.; Li, K.-X.; Okada, T.; Sato, K.; Oka, M. Inhibitors of pentose phosphate pathway cause vasodilation: Involvement of voltage-gated potassium channels. J. Pharmacol. Exp. Ther. 2002, 301, 299-305. [CrossRef]

152. Alzoubi, A.; Toba, M.; Abe, K.; O’Neill, K.D.; Rocic, P.; Fagan, K.A.; McMurtry, I.F.; Oka, M. Dehydroepiandrosterone restores right ventricular structure and function in rats with severe pulmonary arterial hypertension. Am. J. Physiol. Heart Circ. Physiol. 2013, 304, H1708-H1718. [CrossRef]

153. Ventetuolo, C.E.; Baird, G.L.; Barr, R.G.; Bluemke, D.A.; Fritz, J.S.; Hill, N.S.; Klinger, J.R.; Lima, J.A.C.; Ouyang, P.; Palevsky, H.I.; et al. Higher Estradiol and Lower Dehydroepiandrosterone-Sulfate Levels Are Associated with Pulmonary Arterial Hypertension in Men. Am. J. Respir. Crit. Care Med. 2016, 193, 1168-1175. [CrossRef]

154. Dumas de La Roque, E.; Savineau, J.-P.; Metivier, A.-C.; Billes, M.-A.; Kraemer, J.-P.; Doutreleau, S.; Jougon, J.; Marthan, R.; Moore, N.; Fayon, M.; et al. Dehydroepiandrosterone (DHEA) improves pulmonary hypertension in chronic obstructive pulmonary disease (COPD): A pilot study. Ann. Endocrinol. 2012, 73, 20-25. [CrossRef] [PubMed]

155. Sanghvi, V.R.; Leibold, J.; Mina, M.; Mohan, P.; Berishaj, M.; Li, Z.; Miele, M.M.; Lailler, N.; Zhao, C.; de Stanchina, E.; et al. The Oncogenic Action of NRF2 Depends on De-glycation by Fructosamine-3-Kinase. Cell 2019, 178, 807-819.e21. [CrossRef]

156. Beeraka, N.M.; Bovilla, V.R.; Doreswamy, S.H.; Puttalingaiah, S.; Srinivasan, A.; Madhunapantula, S. V The Taming of Nuclear Factor Erythroid-2-Related Factor-2 (Nrf2) Deglycation by Fructosamine-3-Kinase (FN3K)-Inhibitors-A Novel Strategy to Combat Cancers. Cancers 2021, 13, 281. [CrossRef]

157. Sartore, G.; Ragazzi, E.; Burlina, S.; Paleari, R.; Chilelli, N.C.; Mosca, A.; Avemaria, F.; Lapolla, A. Role of fructosamine-3-kinase in protecting against the onset of microvascular and macrovascular complications in patients with T2DM. BMJ Open Diabetes Res. Care 2020, 8, e001256. [CrossRef] [PubMed]

158. Daiber, A.; Chlopicki, S. Revisiting pharmacology of oxidative stress and endothelial dysfunction in cardiovascular disease: Evidence for redox-based therapies. Free Radic. Biol. Med. 2020, 157, 15-37. [CrossRef] [PubMed]

159. Berman, A.Y.; Motechin, R.A.; Wiesenfeld, M.Y.; Holz, M.K. The therapeutic potential of resveratrol: A review of clinical trials. npj Precis. Oncol. 2017, 1, 35. [CrossRef] [PubMed] 